\title{
Alterations of p16-pRb Pathway and Chromosome Locus 9p21-22 in Sporadic Invasive Breast Carcinomas
}

\author{
V. G. Gorgoulis, ${ }^{1}$ E. N. Koutroumbi, ${ }^{1,4}$ A. Kotsinas, \\ P. Zacharatos, ${ }^{1}$ C. Markopoulos, ${ }^{2}$ L. Giannikos, ${ }^{4}$ V. Kyriakou, ${ }^{5}$ \\ Z. Voulgaris, ${ }^{3}$ I. Gogas, ${ }^{2}$ and C. Kittas ${ }^{1}$ \\ Department of ${ }^{1}$ Histology and Embryology, ${ }^{2}$ 2nd Department of \\ Surgery, and ${ }^{3} 1$ st Department of Obstetrics and Gynaecology, School \\ of Medicine, University of Athens, Greece \\ Departments of ${ }^{4}$ Gynaecology and ${ }^{5}$ Pathology, "Laiko" Hospital, \\ Athens, Greece \\ Accepted November 3, 1998.
}

\begin{abstract}
The pl6-pRb pathway represents a vital cell-cycle checkpoint. In the present study we investigated the alterations of this Gl-phase protein pathway using immunohistochemical and molecular methods in a series of 55 breast carcinomas and correlated the findings with clinicopathological features of the patients. Furthermore, we examined its relationship with the status of the chromosomal region 9p2l-22 performing a deletion map analysis because there are indications that, in addition to CDKN2 and MTS2/ $p 15^{I N K 4 B}$ tumor suppressor genes (TSGs), this area harbors other TSG(S).

Aberrant expression (Ab) of pl6 and pRb was observed in $26(47 \%)$ and $16(29 \%)$ of the carcinomas, respectively. A statistical trend pointing out an inverse relationship between $\mathrm{pl} 6$ and $\mathrm{pRb}$ expression was found $(p=0.079)$. Analysis of the region that encodes for $\mathrm{pl} 6$ by deletion mapping, a PCR-based methylation assay and PCR-SSCP, revealed that deletions and transcriptional silencing by methylation might represent the main mechanisms of $C D K N 2 / p 16^{I N K 4 A}$ inactivation in breast carcinomas. The results of deletion mapping also suggest that another TSG(s) may reside at the 9p21-22 area particularly at the $D 9 S 162$ loci and that co-deletion of this putative gene with $C D K N 2 / p 16^{I N K 4 A}$ may play a role in
\end{abstract}

\section{Introduction}

Breast carcinoma is the most common malignant tumor and the second cause of carcinoma death after lung cancer in women (1). Recently, apart from genetic factors, hormonal imbalances, and

Address correspondence and reprint requests to: Dr. Vassilis Gorgoulis, Antaiou 53 Str., Lamprini, Ano Patisia, Athens, GR 11146, Greece. Phone: +30-1-2922143; Fax: +30-17790353 breast carcinogenesis. In addition, microsatellite instability (MI), a marker of replication error phenotype $(\mathrm{RER}+)$, was observed with a frequency of $16 \%$ in the area examined and was inversely related with loss of heterozygosity (LOH). Interestingly, most cases with MI at the region encoding for pl6 were aggregated in a subgroup of breast carcinomas with no other obvious genetic and/or epigenetic CDKN2/p1 $6^{I N K 4 A}$ alterations. We speculate that there is an additional mechanism of CDKN2/p16 ${ }^{I N K 4 A}$ inactivation. The relationship of pl6 protein level $\mathrm{pRb}$, status, the pl6-pRb combined immunoprofiles, and the microsatellite alterations detected at the 9p21-22 locus with the patients' clinicopathological parameters revealed two significant correlations: one between normal $\mathrm{pRb}$ expression and lymph node involvement ( $p=0.0263)$, and the other between microsatellite alterations ( $\mathrm{LOH}$ and or $\mathrm{MI})$ and tumor size $(p=9.2 \times$ $\left.10^{-3}\right)$.

In view of the heterogenous nature of breast cancer, we suggest that in a significant proportion of breast carcinomas, deregulation of the pl6-pRb pathway in association with another, as-yet unidentified, TSG(s) of the 9p21-22 region may play a role in initiating or progressing the oncogenic procedure, while in other subgroups, alternative molecules may play this role. environmental parameters considered to be implicated in breast cancer development, more has been learned of the possible implications of oncogenes and oncosuppressor genes (2). It is not surprising that alterations in the molecular machinery controlling the transition from $\mathrm{Gl}$ to $\mathrm{S}$ phase might represent central events leading to breast cancer generation. In this respect, there is a strong body of evidence that cell-cycle regula- 
tors are involved in human cancer development (3).

Ongoing studies in this field revealed the pl 6 product of $C D K N 2$ gene is an important molecule involved in controlling cell-cycle progression. The CDKN2 gene has been mapped to chromosome region $9 \mathrm{p} 2 \mathrm{l}$ and produces two transcripts ( $a$ and $b$ ) encoding two different proteins, pl $6^{\mathrm{INK} 4 \mathrm{a}}$ and pl9 $9^{\mathrm{ARF}}$, respectively. $\mathrm{Pl} 6^{\mathrm{INK} 4 \mathrm{a}}$, an 156-amino acids (aa) protein with a molecular weight of pl6kDa, functions as an inhibitor of cyclin-dependent kinase 4/6 (CDKs 4/6) $(4,6)$. Retinoblastoma protein $(\mathrm{pRb})$ phosphorylation by CDKs $4 / 6$ is a critical step in cell cycle progression. The pRb protein $\left(\mathrm{pl} 09^{\mathrm{RB} 1}\right)$ consists of $928 \mathrm{aa}$, has a molecular weight of $105 \mathrm{kDa}$, and is encoded by $R B I$ tumor suppresser gene which is located on chromosome region 13q14.2 (reviewed in 7). Uncontrolled phosphorylation of pRb by CDKs $4 / 6$ due, either to loss of functional pl6 or cyclin-Dl overexpression, may lead to irregular cellular proliferation (3). The CDKN2/ INK 4 a gene product seems to be a candidate tumor suppresser protein as it has been found to be non-functional in a high percentage of cell lines and various malignancies $(3,8,9)$. Genetic alterations, including homozygous deletions, mutations, loss of one allele and inactivation of the other probably due to hypermethylation, appear to consist the most common mechanisms led to non-functional $\mathrm{p} 16^{\mathrm{INK} 4 \mathrm{a}}(2,6,7)$. A difference in the frequency of $C D K N 2$ genetic alterations between cell lines and primary tumors may be caused by contamination of cancerous tissue with material derived from the surrounding stromal cells and artifactual or cellular adaptation during cell culture (9-12). A similar explanation has been given for discrepancies found in $\mathrm{pRb}$ studies (13). In a wide spectrum of malignancies such as retinoblastomas, small cell lung carcinoma, bladder, pancreatic and breast carcinomas, $\mathrm{pRb}$ was inactivated by mutations (reviewed in ref. 7). Investigation of $\mathrm{pRb}$ and pl6 protein expression at the single cell level by immunohistochemistry could be the answer to the problem of evaluating the pRb and pl6 alterations using conventional molecular biology methods.

Controversy continues to surround the frequency and mechanisms of $C D K N 2$ gene inactivation in primary breast carcinomas (14-24). In reviewing the world literature published so far, we found four reports dealing with aberrant pl 6 immunoexpression and in situ distribution with percentages ranging from $37 \%$ to $73 \%(14-17,24)$. Although most studies agree that point mutations represent a rather rare mechanism of CDKN2 inactivation $(0-5 \%)(18,20-23,25)$, there is great discrepancy regarding $C D K N 2$ gene deletion, with figures varying from $0 \%$ to $58 \%(20-23,25,26)$. In addition, only two reports deal with the methylation status of the CDKN2 gene in breast cancer, and they report contradicting findings $(19,27)$. A similar discordance seems to exist concerning $\mathrm{pRb}$ inactivation in breast carcinomas $(7-47 \%)$ (14,28-38).

It has been postulated that the pl6-pRb pathway is regulated by a feedback loop involving $\mathrm{pRb}(39,40)$. In such a case, deregulated expression of $\mathrm{pRb}$, by hyperphosphorylation, mutation, or association with viral oncoproteins, would permit high levels of pl6. The existence of this inverse relationship in breast carcinomas is not clear yet $(14,17,24)$.

The goals of the present study were to investigate the expression of pl6 and pRb and their interrelationship in a series of 55 surgically resected sporadic invasive breast carcinomas; to correlate the findings with clinicopathological parameters and the hormonal status of the patients; and to look into the mechanisms of $p 16^{I N K 4 A}$ inactivation. Finally, we sought to examine the state of the chromosomal region 9p21-22 because there are indications that, in addition to CDKN2, MTS2/p $15^{I N K 4 B}$, and methylthioadenosine phosphorylase (MTAP) tumorsuppressor genes (TSGs), it harbors another TSG(s) $(26,41,42)$.

\section{Materials and Methods}

Tissue Samples

Specimens from 55 breast carcinomas (collected between November 1995 and December 1996) were obtained in less than 15 min after surgery. Two samples of each tumor were taken; one was snap-frozen in liquid nitrogen and stored at $-70^{\circ} \mathrm{C}$, the other was formalin-fixed and paraffin-embedded (FFPE). In addition, adjacent normal tissue was included from each specimen examined. The material comprised 48 ductal, 4 lobular, and 3 mixed invasive carcinomas. Microscopic grading and surgical staging of the tumors was based on the Nottingham modification of the Bloom-Richardson (43) and TNM systems (44), respectively. The age, histology, grade, tumor size, lymph node status, stage, patient's "follow-up", and estrogen (ER) and progesterone receptor (PgR) levels are presented in Table 1 . None of the 
tumors were from women with a strong family history of breast cancer.

\section{Estrogen and Progesterone Receptor Status}

ER and PgR levels were measured with the ligand-binding assay according to the EORTC Breast Cancer Cooperative Group procedures (45).

\section{Immunohistochemistry}

ANTIBODIES. For immunohistochemical analysis of pl 6 and pRb, the following antibodies (Abs) were used: C-20 (class: IgG rabbit polyclonal, epitope: residues 137-156 of the $C$ terminus of pl6) (Santa Cruz, CA); F-12 (class: IgG2a mouse monoclonal, epitope: residues 1-167 representing the full-length pl6) (Santa Cruz, CA), and Rbl (class: IgGl, mouse monoclonal, epitope: residues 375-658) (Dako, Denmark).

METHOD. First, 5- $\mu \mathrm{m}$ paraffin sections of the lesions were mounted on poly-L-lysine-coated slides, dewaxed, rehydrated, and incubated for 30 min with $0.3 \%$ hydrogen peroxide to quench the endogenous peroxidase activity. Unmasking of pl6 and pRb proteins was then carried out with the heat-mediated antigen retrieval (HMAR) method, as previously described $(46,47)$, when the MAbs, F-12 and Rbl were applied. The immunohistochemical assay for PAb C-20 did not include antigen retrieval step. The sections were incubated with the antibodies at a 1:100 dilution at $4^{\circ} \mathrm{C}$ overnight. Biotin-conjugated secondary antibody was added at a 1:200 dilution for $1 \mathrm{hr}$ at room temperature (RT). Next stage comprised a 20-min incubation in Strept AB Complex solution (streptavidin stock solution 1:100 and biotin-hyperoxydase stock solution 1:100 in TBS) (Dako, Denmark). For color development we used 3,3'-diaminobenzidine tetrahydrochloride (DAB) and hematoxylin as counterstain.

CONTROls. The HeLa and Lo Vo cell lines with well-defined pl6 and pRb status, respectively, were used as positive controls. Mouse $\operatorname{IgGl}$ monoclonal antibody (MAb) of unrelated specificity and the IgG fraction of normal rabbit serum were used as negative controls. Furthermore, the specificity of pl 6 staining with the PAb C-20 was tested by incubating the latter with the control peptide C-20P, against which it was raised, and applying it on the sections. Elimination of staining verified pl 6 positivity.
EVALUATION. For scoring the pl 6 and pRb staining patterns we used previously published criteria $(16,30)$. Cytoplasmic reactivity was disregarded and only nuclear staining above any cytoplasmic background was considered evidence of expression of the pl 6 and pRb proteins. The samples were divided into two categories: (1) pl 6 or pRb normal (NE), when more than $90 \%$ of the tumor nuclei were stained, and (2) pl6 or $\mathrm{pRb}$ abnormal (AE), when there was absence of nuclear staining in a portion of (heterogeneous) or in the entire (homogeneous) tumor section, while admixed non-neoplastic cells showed nuclear reactivity. A mosaic pattern of staining with absence of pl 6 or $\mathrm{pRb}$ reactivity in a proportion of tumor cells was not interpreted as abnormal. If there was no discreanable nuclear staining in either tumor or stroma, the stain was regarded inconclusive.

\section{Microdissection and DNA Extraction}

DNA was extracted from adjacent 5 - $\mu \mathrm{m}$ sections of each frozen tumor specimen. Contiguous $5-\mu \mathrm{m}$ sections were processed and the first section was stained with hematoxylin and eosin to visualize the extent of the tumor cells within each sample. The boundaries of the cancerous tissue were delineated microscopically and excess normal tissues were removed with sterile surgical blades, as previously described (48). The remaining neoplastic material was digested in $500 \mu \mathrm{l}$ lysis solution [ $50 \mathrm{mM}$ Tris$\mathrm{HCl}(\mathrm{pH} \mathrm{8.0}), 150 \mathrm{mM} \mathrm{NaCl}, 5 \mathrm{mM}$ EDTA, containing $1 \%$ SDS, and proteinase $\mathrm{K}$ (BoehringerMannheim) at a final concentration of $100 \mu \mathrm{g} / \mathrm{ml}]$. Lysis was carried out in a $55^{\circ} \mathrm{C}$ water bath for 48 hr. Additional proteinase $\mathrm{K}(50 \mu \mathrm{g} / \mathrm{ml})$ was added on each day of lysis. DNA was extracted from the supernatant using the phenol:chloroform:isoamylalcohol method (49).

\section{Microsatellite Alteration Analysis of Chromosomal Region 9p21-22}

METHOD. DNA from normal and cancerous tissue was amplified by polymerase chain reaction (PCR) using a tight cluster of highly polymorphic microsatellite markers spanning ll cM across 9p2l-22 with the following order from telomeric $9 \mathrm{p}$ to centromeric $9 \mathrm{p}$ (Fig. 1A): D9SI62 (172-196 bp), IFNA (138-150 bp), D9SI71 (159-177 bp), and D9S126 (226-250 bp) (Research Genetics, Hunstville, USA). The 50- $\mu$ l reaction mixture contained $5 \mu$ l of DNA solution (100 ng), $10 \mu \mathrm{M}$ Tris- $\mathrm{HCl}(\mathrm{pH} 8.8), 50 \mu \mathrm{M} \mathrm{KCl}, 2.5 \mathrm{mM}$ $\mathrm{MgCl}_{2}, 0.1 \%$ Triton X-100, $200 \mu \mathrm{M}$ of each dNTP 
Table 1. Summary of clinicopathological features, immunohistochemical results, and 9p21 chromosomal locus LOH analysis results

\begin{tabular}{|c|c|c|c|c|c|c|c|c|c|c|c|c|c|}
\hline \multicolumn{10}{|c|}{ Clinicopathological Features } & \multicolumn{2}{|c|}{$\begin{array}{l}\text { Immuno- } \\
\text { phenotypes }\end{array}$} & \multicolumn{2}{|c|}{$\begin{array}{l}\text { Molecular } \\
\text { Analysis }\end{array}$} \\
\hline Sample & Age & H-P & TS & $\mathbf{G R}$ & $\mathbf{E R}$ & $\mathbf{P R}$ & $\mathbf{L N}$ & Stage & $\begin{array}{c}\text { Patients' }^{\prime} \\
\text { Follow-up }\end{array}$ & IHC P16 & IHC Rb & LOH(c) & LOH(f) \\
\hline 54 & 63 & DIN & $<2$ & II & $\mathrm{N}$ & $\mathrm{N}$ & No & I & $22+$ & $\mathrm{AE}$ & $\mathrm{AE}$ & $\mathrm{L}$ & $\mathbf{L}$ \\
\hline 29 & 69 & DIN & $>2$ & II & $P$ & $\mathrm{P}$ & No & II & $28+$ & $\mathrm{AE}$ & $\mathrm{AE}$ & MI & MI \\
\hline 24 & 52 & LIN & $>2$ & & $\mathbf{P}$ & $\mathrm{P}$ & No & II & $29+$ & $\mathrm{AE}$ & $\mathrm{AE}$ & MI & MI \\
\hline 49 & 42 & DIN & $>2$ & II & $\mathrm{P}$ & $\mathrm{P}$ & Yes & III & $22+$ & $\mathrm{AE}$ & $\mathrm{AE}$ & NI & $\mathrm{H}$ \\
\hline 46 & 67 & DIN & $<2$ & II & $P$ & $P$ & Yes & I & $25+$ & $\mathrm{AE}$ & NE & $\mathrm{H}$ & $\mathrm{H}$ \\
\hline 8 & 80 & DIN & $=2$ & II & $P$ & $\mathrm{~N}$ & Yes & II & $32+$ & $\mathrm{AE}$ & NE & $\mathrm{H}$ & $\mathrm{H}$ \\
\hline 33 & 64 & DIN & $>2$ & III & $P$ & $\mathrm{P}$ & Yes & II & $27+$ & $\mathrm{AE}$ & NE & $\mathrm{H}$ & $\mathrm{H}$ \\
\hline 38 & 67 & DIN & $>2$ & II & $P$ & $P$ & No & II & $27+$ & $\mathrm{AE}$ & $\mathrm{NE}$ & $\mathrm{H}$ & $\mathrm{H}$ \\
\hline 40 & 90 & Mixed & $=2$ & II & $P$ & $\mathrm{~N}$ & Yes & IV & $27+$ & $\mathrm{AE}$ & $\mathrm{NE}$ & $\mathrm{H}$ & $\mathrm{H}$ \\
\hline 10 & 61 & DIN & $>2$ & II & $P$ & $\mathrm{P}$ & Yes & III & $32+$ & $\mathrm{AE}$ & NE & $\mathrm{H}$ & MI \\
\hline 43 & 73 & DIN & $<2$ & I & UN & UN & Yes & II & $26+$ & $\mathrm{AE}$ & $\mathrm{NE}$ & $\mathrm{H}$ & NI \\
\hline 45 & 45 & DIN & $<2$ & I & $P$ & $\mathrm{P}$ & Yes & II & $25+$ & $\mathrm{AE}$ & $\mathrm{NE}$ & $\mathrm{H}+\mathrm{MI}$ & $\mathrm{H}$ \\
\hline 20 & 60 & DIN & $>2$ & II & $\mathrm{P}$ & $\mathrm{P}$ & No & II & $30+$ & $\mathrm{AE}$ & $\mathrm{NE}$ & L & $\mathrm{H}$ \\
\hline 23 & 64 & DIN & $=2$ & II & $\mathrm{P}$ & $\mathrm{N}$ & No & I & $29+$ & $\mathrm{AE}$ & $\mathrm{NE}$ & $\mathrm{L}$ & $\mathrm{L}$ \\
\hline 1 & 67 & DIN & $>2$ & III & $P$ & $\mathrm{~N}$ & Yes & IV & $35+$ & $\mathrm{AE}$ & $\mathrm{NE}$ & $\mathrm{L}$ & $\mathrm{L}$ \\
\hline 12 & 39 & DIN & $>2$ & II & $\mathbf{P}$ & $\mathrm{P}$ & Yes & III & $31+$ & $\mathrm{AE}$ & $\mathrm{NE}$ & $\mathrm{L}$ & $\mathrm{L}$ \\
\hline 32 & 66 & DIN & $>2$ & II & $P$ & $\mathrm{~N}$ & Yes & III & $27+$ & $\mathrm{AE}$ & $\mathrm{NE}$ & $\mathrm{L}$ & $\mathrm{L}$ \\
\hline 14 & 78 & DIN & $>2$ & III & $\mathrm{P}$ & $\mathrm{N}$ & No & II & $31+$ & $\mathrm{AE}$ & $\mathrm{NE}$ & $\mathrm{L}$ & $\mathrm{NI}$ \\
\hline 27 & 51 & DIN & $>2$ & II & $\mathrm{P}$ & $\mathrm{P}$ & Yes & III & $28+$ & $\mathrm{AE}$ & $\mathrm{NE}$ & $\mathrm{L}$ & $\mathrm{NI}$ \\
\hline 34 & 70 & DIN & $>2$ & II & $\mathrm{P}$ & $\mathrm{P}$ & Yes & III & $27+$ & $\mathrm{AE}$ & $\mathrm{NE}$ & $\mathrm{L}+\mathrm{MI}$ & NI \\
\hline 22 & 57 & DIN & $>2$ & III & $\mathrm{P}$ & $\mathrm{P}$ & No & II & $29+$ & $\mathrm{AE}$ & $\mathrm{NE}$ & MI & $\mathrm{H}$ \\
\hline 21 & 75 & DIN & $>2$ & II & $\mathrm{P}$ & $\mathrm{P}$ & Yes & IV & $29+$ & $\mathrm{AE}$ & $\mathrm{NE}$ & $\mathrm{NI}$ & $\mathrm{H}$ \\
\hline 52 & 66 & DIN & $>2$ & I & UN & UN & Yes & II & $22+$ & $\mathrm{AE}$ & $\mathrm{NE}$ & $\mathrm{NI}$ & $\mathrm{H}$ \\
\hline 28 & 55 & DIN & $>2$ & III & $\mathrm{P}$ & $\mathrm{N}$ & Yes & III & $28+$ & $\mathrm{AE}$ & $\mathrm{NE}$ & $\mathrm{NI}$ & $\mathrm{NI}$ \\
\hline 26 & 56 & LIN & $<2$ & & UN & UN & No & I & $29+$ & $\mathrm{AE}$ & $\mathrm{NE}$ & $\mathrm{NI}$ & $\mathrm{NI}$ \\
\hline 47 & 71 & Mixed & $<2$ & II & $\mathrm{P}$ & $\mathrm{P}$ & Yes & II & $24+$ & $\mathrm{AE}$ & $\mathrm{NE}$ & NI & NI \\
\hline 55 & 39 & Mixed & $<2$ & II & $\mathrm{N}$ & $\mathrm{P}$ & Yes & II & $22+$ & NI & $\mathrm{AE}$ & NI & NI \\
\hline 53 & & LIN & $>2$ & & $\mathrm{P}$ & $\mathrm{P}$ & Yes & IV & $22+$ & $\mathrm{NI}$ & $\mathrm{NE}$ & $\mathrm{L}$ & $\mathrm{NI}$ \\
\hline 13 & 57 & DIN & $<2$ & I & $\mathrm{P}$ & $\mathrm{P}$ & No & I & $31+$ & $\mathrm{NI}$ & $\mathrm{AE}$ & NI & $\mathrm{H}$ \\
\hline 25 & 74 & DIN & $>2$ & III & $\mathrm{P}$ & $\mathrm{N}$ & Yes & II & $29+$ & $\mathrm{NI}$ & $\mathrm{NE}$ & $\mathrm{L}$ & NI \\
\hline 9 & 38 & DIN & $<2$ & II & $\mathrm{P}$ & $\mathrm{P}$ & Yes & I & $32+$ & $\mathrm{NE}$ & $\mathrm{AE}$ & $\mathrm{H}$ & $\mathrm{H}$ \\
\hline 2 & 81 & DIN & $=2$ & II & $\mathrm{P}$ & $\mathrm{P}$ & No & I & $33+$ & $\mathrm{NE}$ & $\mathrm{AE}$ & $\mathrm{H}$ & $\mathrm{H}$ \\
\hline 6 & 69 & DIN & $=2$ & II & $\mathrm{P}$ & $\mathrm{P}$ & Yes & II & $32+$ & $\mathrm{NE}$ & $\mathrm{AE}$ & $\mathrm{H}$ & $\mathrm{H}$ \\
\hline 30 & 77 & DIN & $>2$ & III & $\mathrm{N}$ & $\mathrm{N}$ & No & II & $28+$ & $\mathrm{NE}$ & $\mathrm{AE}$ & $\mathrm{H}$ & $\mathrm{H}$ \\
\hline 39 & 88 & DIN & $>2$ & II & $\mathrm{P}$ & $\mathrm{P}$ & No & II & $27+$ & $\mathrm{NE}$ & $\mathrm{AE}$ & $\mathrm{H}$ & $\mathrm{H}$ \\
\hline 42 & 54 & DIN & $>2$ & II & $\mathrm{P}$ & $\mathrm{P}$ & No & II & $26+$ & $\mathrm{NE}$ & $\mathrm{AE}$ & $\mathrm{H}$ & $\mathrm{H}$ \\
\hline 11 & 81 & DIN & $<2$ & I & $\mathrm{P}$ & $\mathrm{P}$ & No & I & $32+$ & $\mathrm{NE}$ & $\mathrm{AE}$ & $\mathrm{H}$ & $\mathrm{NI}$ \\
\hline 18 & 65 & DIN & $=2$ & III & $\mathrm{P}$ & $P$ & Yes & III & $30+$ & $\mathrm{NE}$ & $\mathrm{AE}$ & $\mathrm{H}$ & $\mathrm{NI}$ \\
\hline 31 & 73 & DIN & $=2$ & II & $\mathrm{P}$ & $\mathrm{N}$ & Yes & II & $28+$ & $\mathrm{NE}$ & $\mathrm{AE}$ & NI & $\mathrm{H}$ \\
\hline 16 & 53 & DIN & $<2$ & III & $P$ & $\mathrm{~N}$ & Yes & III & $31+$ & $\mathrm{NE}$ & $\mathrm{AE}$ & $\mathrm{NI}$ & $\mathrm{NI}$ \\
\hline 3 & 58 & DIN & $>2$ & III & $\mathrm{N}$ & $\mathrm{N}$ & No & II & $32+$ & $\mathrm{NE}$ & $\mathrm{NI}$ & NI & NI \\
\hline 41 & 64 & DIN & $<2$ & II & UN & UN & Yes & II & $26+$ & $\mathrm{NE}$ & $\mathrm{NE}$ & $\mathrm{H}$ & $\mathbf{H}$ \\
\hline 44 & 66 & DIN & $<2$ & I & $\mathrm{N}$ & $\mathrm{N}$ & No & I & $25+$ & $\mathrm{NE}$ & $\mathrm{NE}$ & $\mathrm{H}$ & $\mathrm{H}$ \\
\hline 15 & 48 & DIN & $=2$ & I & $P$ & $\mathrm{~N}$ & Yes & II & $30+$ & $\mathrm{NE}$ & $\mathrm{NE}$ & $\mathrm{H}$ & $\mathrm{H}$ \\
\hline 35 & 72 & DIN & $=2$ & I & $\mathrm{P}$ & $\mathrm{P}$ & Yes & I & $27+$ & $\mathrm{NE}$ & $\mathrm{NE}$ & $\mathrm{H}$ & $\mathrm{H}$ \\
\hline 7 & 46 & DIN & $>2$ & II & $P$ & $P$ & Yes & I & $32+$ & $\mathrm{NE}$ & $\mathrm{NE}$ & $\mathrm{H}$ & $\mathbf{H}$ \\
\hline 36 & 62 & DIN & $>2$ & II & $\mathrm{P}$ & $\mathrm{P}$ & Yes & III & $27+$ & NE & $\mathrm{NE}$ & $\mathrm{H}$ & $\mathrm{H}$ \\
\hline 37 & 65 & DIN & $>2$ & III & $P$ & $\mathrm{~N}$ & Yes & III & $27+$ & $\mathrm{NE}$ & $\mathrm{NE}$ & $\mathrm{H}$ & $\mathrm{H}$ \\
\hline
\end{tabular}


Table 1. Summary of clinicopathological features, immunohistochemical results, and 9p21 chromosomal locus LOH analysis results (cont.)

\begin{tabular}{|c|c|c|c|c|c|c|c|c|c|c|c|c|c|}
\hline \multicolumn{10}{|c|}{ Clinicopathological Features } & \multicolumn{2}{|c|}{$\begin{array}{l}\text { Immuno- } \\
\text { phenotypes }\end{array}$} & \multicolumn{2}{|c|}{$\begin{array}{c}\text { Molecular } \\
\text { Analysis }\end{array}$} \\
\hline Sample & Age & $\mathbf{H}-\mathbf{P}$ & TS & GR & $\mathbf{E R}$ & $\mathbf{P R}$ & $\mathbf{L N}$ & Stage & $\begin{array}{c}\text { Patients' } \\
\text { Follow-up }\end{array}$ & IHC P16 & IHC Rb & LOH(c) & LOH(f) \\
\hline 4 & 66 & DIN & $>2$ & II & $\mathrm{N}$ & $\mathrm{N}$ & Yes & III & $32+$ & NE & NE & $\mathrm{H}$ & $\mathrm{L}$ \\
\hline 17 & 66 & DIN & $>2$ & III & $\mathrm{P}$ & $\mathbf{P}$ & Yes & III & $30+$ & $\mathrm{NE}$ & NE & $\mathrm{H}$ & MI \\
\hline 5 & 60 & DIN & $<2$ & II & $\mathrm{P}$ & $\mathbf{P}$ & No & I & $32+$ & $\mathrm{NE}$ & NE & $\mathrm{H}$ & NI \\
\hline 19 & 64 & LIN & $>2$ & & $P$ & $P$ & Yes & III & $30+$ & $\mathrm{NE}$ & NE & $\mathrm{H}+\mathrm{MI}$ & $\mathrm{H}$ \\
\hline 51 & 60 & DIN & $=2$ & I & $P$ & $\mathrm{~N}$ & Yes & I & $22+$ & $\mathrm{NE}$ & $\mathrm{NE}$ & L & $\mathrm{H}$ \\
\hline 48 & 75 & DIN & $=2$ & II & UN & UN & Yes & II & $24+$ & NE & $\mathrm{NE}$ & $\mathrm{NI}$ & $\mathbf{H}$ \\
\hline 50 & 35 & DIN & $=2$ & III & $\mathrm{N}$ & $\mathrm{P}$ & Yes & II & $22+$ & NE & $\mathrm{NE}$ & $\mathrm{NI}$ & $\mathrm{H}$ \\
\hline
\end{tabular}

Abbreviations: H-P, histology; TS, tumor size (in $\mathrm{cm}$ ); GR, grade; ER/PR, estrogen and progesterone receptor estimation, respectively; LN, lymph nodes metastases; IHC, immunohistochemistry; DIN, ductal invasive carcinoma; LIN, lobular invasive carcinoma; $\mathrm{N}$, negative (normal expression); $\mathrm{P}$, positive (overexpression); UN, undetected level; $\mathrm{AE}$, aberrant expression; NI, noninformative; NE, normal expression; L, LOH loss of heterozygosity; MI, microsatellite instability; $\mathrm{H}$, heterozygous.

${ }^{a}$ Note: The number indicates months of survival after surgery, $(+)$ indicates that the patient is alive.

(dATP, dCTP, dGTP, and dTTP), I $\mu \mathrm{M}$ of each marker pair, and 1.5 units of Taq DNA polymerase (Promega, Madison, USA). The thermal cycle profile was denaturation at $95^{\circ} \mathrm{C}$ for $10 \mathrm{~min}$ before the addition of Taq polymerase, followed by 30 cycles with incubations of $40 \mathrm{sec}$ at $95^{\circ} \mathrm{C}, 35 \mathrm{sec}$ at $56^{\circ} \mathrm{C}$, and $30 \mathrm{sec}$ at $72^{\circ} \mathrm{C}$. The products were analyzed on $10 \%$ polyacrylamide gels containing $10 \%$ glycerol. Visualization was carried out by silver staining (49).

CONTROL. To determine whether the PCR product was a microsatellite region, denaturating polyacrylamide gels were used. The bands corresponding to the microsatellite regions, due to the higher existence of dinucleotide repeats, are separated according to their molecular weight. Furthermore, all samples showing changes in microsatellite sequences were verified by subjecting the corresponding DNA sample to a second, independent PCR analysis. This, as well as control PCR reactions lacking DNA, were done to eliminate the chance of false-positives due to PCR artifacts or sample contamination. Finally, for microsatellite instability (MI) determination, we used previously published criteria (50).

\section{Methylation Analysis of the CDKN2 Gene}

PRIMERS. A 239-bp fragment of exons la was amplified using the following primers, employing the Oligo Software v.4.01: pl6AU: 5'GGAGAGGGGGAGAGCAGGCA-3', pl6AD: 5'CTCCAGAGTCGCCCGCCATC- $3^{\prime}$.
METHOD. The inability of some restriction enzymes to cut methylated sequences was used to examine the methylation status of exon la. There are two HpaII sites and one KspI site (both restriction enzymes are methylationsensitive) within exon la. One microgram of genomic DNA from matched normal and tumor samples was digested overnight with HpaII and $K s p I$ as previously described (51). Five microliters of the digested DNA solutions was used as a template in a 50- $\mu$ l reaction mixture containing $10 \mu \mathrm{M}$ Tris- $\mathrm{HCl}(\mathrm{pH} \mathrm{8.8)}, 50 \mu \mathrm{M}$ $\mathrm{KCl}, 1.5 \mathrm{mM} \mathrm{MgCl}_{2}, 0.1 \%$ Triton X-100, $5 \%$ DMSO, $5 \%$ glycerol, $200 \mu \mathrm{M}$ of each dNTP (dATP, dCTP, dGTP and dTTP), $1 \mu \mathrm{M}$ of each primer, and 1.5 units of Taq DNA polymerase (Promega). The thermal cycle profile was denaturation at $95^{\circ} \mathrm{C}$ for $10 \mathrm{~min}$ before the addition of Taq polymerase, followed by 30 cycles with incubations of $1 \mathrm{~min}$ at $95^{\circ} \mathrm{C}, 45 \mathrm{sec}$ at $57^{\circ} \mathrm{C}$, and $45 \mathrm{sec}$ at $72^{\circ} \mathrm{C}$. PCR products were separated on $2 \%$ agarose gels.

EVALUATION OF CONTROLS. When exon la of the $C D K N 2$ gene is methylated, the methylation-sensitive restriction enzyme fails to cut and a PCR product is obtained. For each specimen analyzed, undigested and non-methyl-sensitive MspI-digested samples served as positive and negative controls, respectively, as previously described (51). Finally, as methylation-positive samples we evaluated only the cases with reproducible results. 

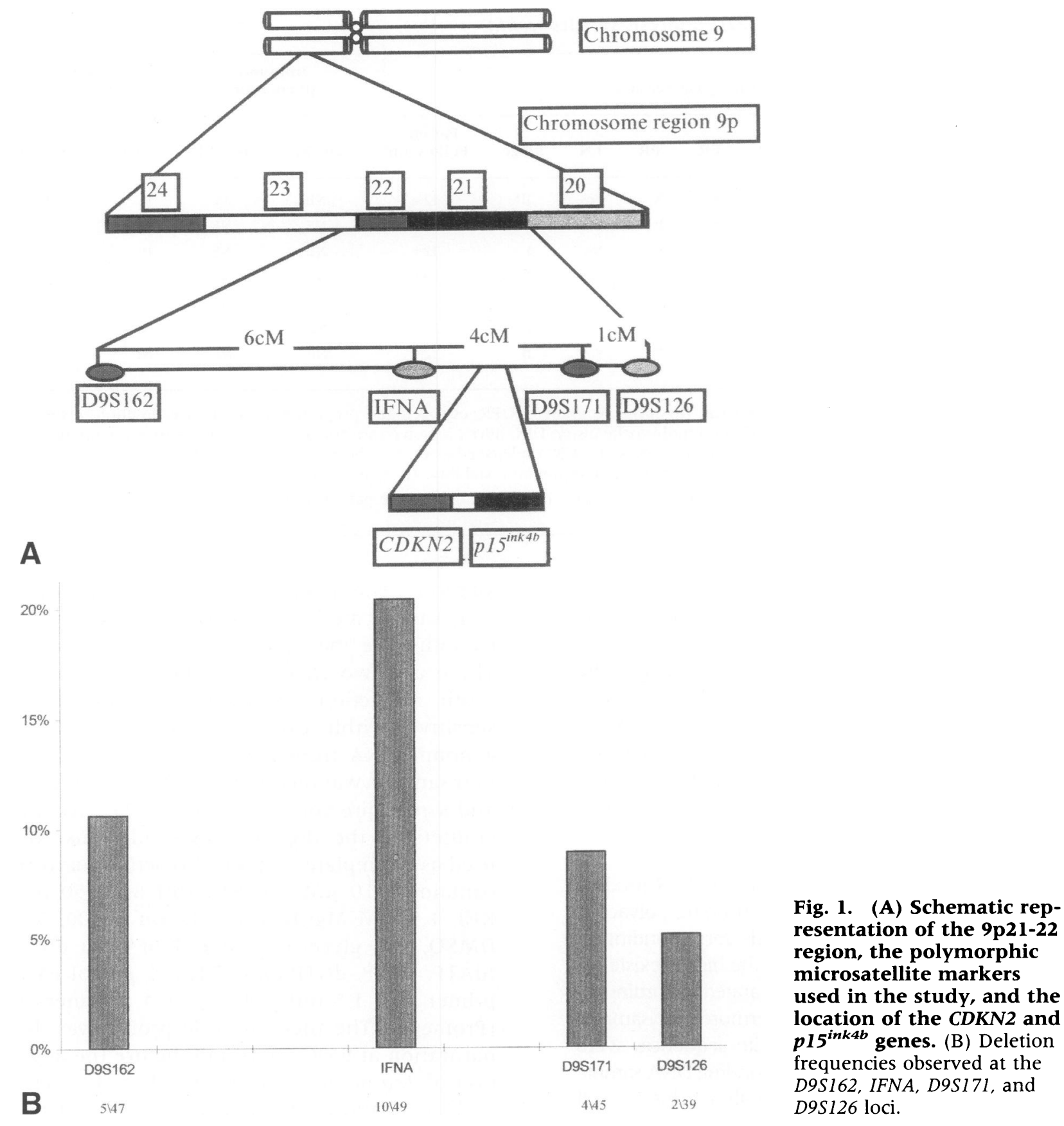

Single-Strand Conformation Polymorphism Analysis of CDKN2/p1 $6^{\mathrm{INK} 4 \mathrm{~A}}$ Gene

PRIMERS. The primers used for methylation analysis of exon la: pl6BU: 5'-GGCTCTGACCATTCTGTTCTCTC-3'. pl6BD: 5'-GGCTGAACTTTCTGTGCTGG-3', designed by using Oligo Software v.4.01, for exon 2 of CDKN2/p16 $6^{I N K 4 A}$ (419 bp PCR-amplified fragment) were used for mutation analysis.
METHOD. Single-strand conformation analysis was performed on normal and tumor tissuederived DNA as previously described (52).

\section{Statistical Analysis}

Statistical analysis was based on the $\operatorname{chi}\left(\chi^{2}\right)$-test with Yates' correction. An additional two-tailed Fisher's exact test was applied only when the number of samples in any cell of a given statis- 
tical table was $\leq 5$. The statistical difference was considered significant if $p<0.05$.

\section{Results \\ Immunohistochemistry}

IMMUNOHISTOCHEMICAL EXPRESSION OF p16 AND pRb PROTEINS AND RELATIONSHIP WITH VARIOUS CLINICOPATHOLOGICAL PARAMETERS. Immunohistochemical analysis revealed aberrant expression of $\mathrm{pl} 6$ and $\mathrm{pRb}$ in $26(47 \%)$ and $16(29 \%)$ of the 55 carcinomas, respectively (Table 1; Figs. 2, 3). There was concordance of pl6 staining with both antibodies used. In four cases, staining was regarded inconclusive. $\mathrm{Pl} 6$ and $\mathrm{pRb}$ results and their relation to age, grade, tumor size, lymph node status, stage, and hormonal status are presented in Table 2 . Statistical analysis did not reveal any significant correlations with the exception of an association between $\mathrm{pRb}$ expression and lymph node status $[\mathrm{pRb}(\mathrm{No}) / \mathrm{LN}(+) \quad 30 / 37 \quad(81 \%)$ vs. $\mathrm{pRb}(\mathrm{No}) /$ $\mathrm{LN}(-) 8 / 17(47 \%) p=0.0263]$.

INTERRELATION BETWEEN pl6 AND pRb EXPRESSION. There was a statistical trend pointing out an inverse relation between pl 6 and pRb expression. Breast carcinomas with strong $\mathrm{pRb}$ expression showed frequently abnormal pl6 staining (22/50), wheras tumors with aberrant $\mathrm{pRb}$ expression were more likely to be positive for $\mathrm{pl} 6(10 / 50) \quad[\mathrm{pRb}(\mathrm{No}) / \mathrm{pl} 6(\mathrm{Ab}): \quad 14 / 24$ $(58.3 \%)$ vs. $\mathrm{pRb}(\mathrm{No}) / \mathrm{pl} 6(\mathrm{No}): 22 / 26$ (84.6\%) $p=0.079]$.

RELATION BETWEEN COMBINED p 16-pRb IMMUNOPROFILES AND VARIOUS CLINICOPATHOLOGICAL PARAMETERS. The statistical analysis did not show any significant associations as presented in Table 2 .

\section{Microsatellite Alteration Analysis of Chromosomal Region 9p21-22}

For microsatellite analysis (MA) analysis we used a tight cluster of highly polymorphic microsatellite markers spanning 11 cM across 9p21-22 with the following order from telomeric $9 p$ to centromeric 9p (Fig. 1A): D9S162, IFNA, D9S171, and D9S126 (Fig. 1A).

Out of 55 cases, $47(85 \%)$ were informative for D9S162, $49(89 \%)$ for IFNA, $45(82 \%)$ for D9S171, and $39(71 \%)$ for D9S126. Thirteen $(24 \%)$ breast carcinomas displayed loss of heterozygosity (LOH) in one or more markers (Fig. 4A). The deletion frequencies for each
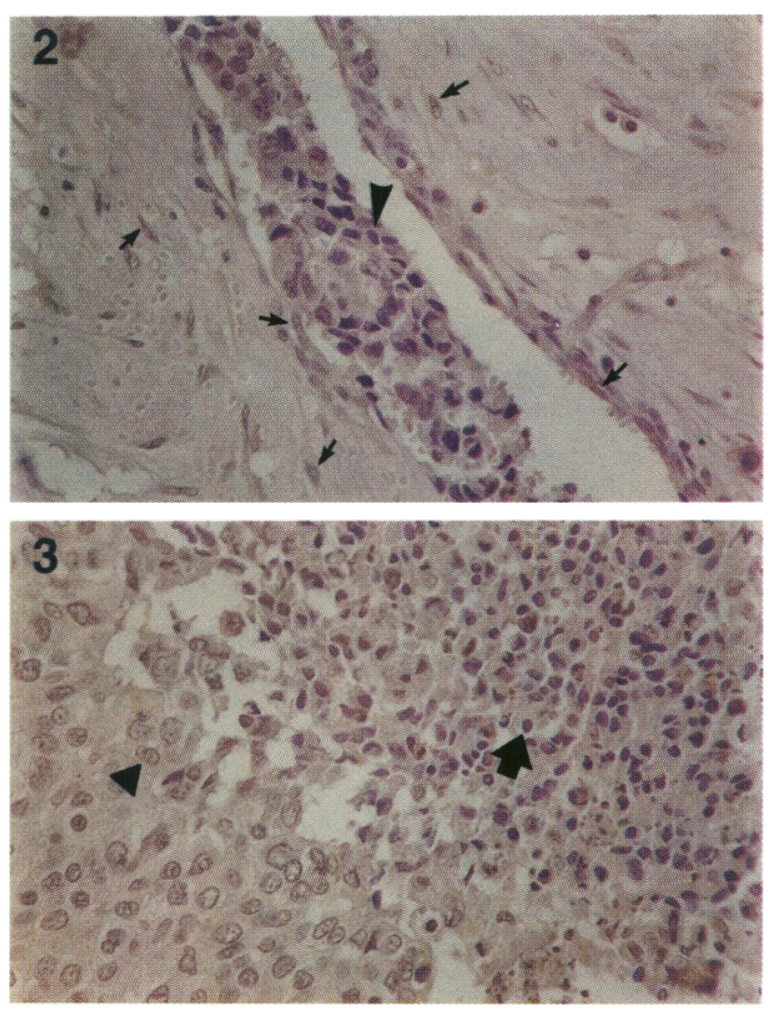

Fig. 2. Ductal breast carcinoma with homogenous aberrant pl6 expression (tumor region indicated by arrowhead). Stromal cells (fibroblasts) with normal pl6 staining (arrows). Streptavidin-biotin peroxidase technique with F-12 anti-pl6 antibody (see Materials and Methods) and hematoxylin counterstain $(\times 500)$.

Fig. 3. Ductal breast carcinoma with heterogenous aberrant $p R b$ expression (the area with pRb normal expression is indicated with an arrowhead whereas the absence of $\mathrm{pRb}$ expression is indicated by an arrow). Streptavidin-biotin peroxidase technique with $\mathrm{Rbl}$ anti-pRb antibody (see Materials and Methods) and hematoxylin counterstain $(\times 500)$.

marker are presented in Figure 1B. The results were further categorized into three groups. Group $\mathrm{LOH}(\mathrm{c})$, the cases demonstrating a central LOH at the IFNA and/or D9S171 loci, indicating a possible deletion of the CDKN2 gene; group $\mathrm{LOH}(\mathrm{f})$, the patients with chromosomal abnormalities at the flanks upstream of IFNA and/or downstream of $D 9 S 171$; and group $\mathrm{LOH}(-)$, the cases with no indication of $\mathrm{LOH}$ and/or noninformative (NI) samples. Seven of the 55 patients were placed in group $\mathrm{LOH}(\mathrm{c}), 1$ in group $\mathrm{LOH}(\mathrm{f})$, 5 in both groups: $\mathrm{LOH}(\mathrm{c})$ and $\operatorname{LOH}(\mathrm{f})$, and 42 in group $\mathrm{LOH}(-)$ (Table 1 ).

Apart from chromosomal deletions, 9 (16\%) patients demonstrated MAs, which appeared as an expansion or a compression of a single or 
Table 2. Relationship of immunohistochemical results with various clinicopathological parameters

\begin{tabular}{|c|c|c|c|c|c|c|c|c|c|c|c|c|c|c|c|c|c|c|c|c|c|c|}
\hline \multirow[b]{2}{*}{ IHC } & \multicolumn{4}{|c|}{ Tumor Size $(\mathrm{cm})$} & \multicolumn{3}{|c|}{$\begin{array}{l}\text { Lymph Node } \\
\text { Metastasis }\end{array}$} & \multicolumn{4}{|c|}{ Grade } & \multicolumn{5}{|c|}{ Stage } & \multicolumn{3}{|c|}{ ER } & \multicolumn{3}{|c|}{ PR } \\
\hline & $<2$ & 2 & $>2$ & $p$ & No & Yes & $p$ & $\mathbf{I}$ & II & III & $p$ & $\mathbf{I}$ & II & III & IV & $p$ & $\mathbf{P}$ & $\mathbf{N}$ & $p$ & $\mathbf{P}$ & $\mathbf{N}$ & $p$ \\
\hline \multicolumn{23}{|l|}{ pl6 } \\
\hline $\mathrm{NE}$ & 6 & 9 & 10 & & 8 & 17 & & 5 & 13 & 7 & & 7 & 10 & 8 & 0 & & 7 & 18 & & 11 & 14 & \\
\hline $\mathrm{AE}$ & 6 & 3 & 17 & 0.091 & 9 & 17 & 0.921 & 3 & 18 & 5 & 0.445 & 4 & 12 & 7 & 3 & 0.256 & 4 & 22 & 0.45 & 11 & 15 & 0.87 \\
\hline Total & 12 & 12 & 27 & & 17 & 34 & & 8 & 31 & 12 & & 11 & 22 & 15 & 3 & & 11 & 40 & & 22 & 29 & \\
\hline \multicolumn{23}{|l|}{$p R b$} \\
\hline $\mathrm{NE}$ & 8 & 8 & 22 & & 8 & 30 & & 7 & 22 & 9 & & 7 & 16 & 11 & 4 & & 8 & 30 & & 18 & 20 & \\
\hline $\mathrm{AE}$ & 6 & 4 & 6 & 0.340 & 9 & 7 & 0.026 & 2 & 11 & 3 & 0.749 & 5 & 7 & 4 & 0 & 0.460 & 3 & 13 & 0.85 & 4 & 12 & 0.22 \\
\hline Total & 14 & 12 & 28 & & 17 & 37 & & 9 & 33 & 12 & & 12 & 23 & 15 & 4 & & 11 & 43 & & 22 & 32 & \\
\hline \multicolumn{23}{|l|}{$p 16 / p R b$} \\
\hline $\mathrm{NE} / \mathrm{NE}$ & 3 & 5 & 6 & & 2 & 12 & & 4 & 7 & 3 & & 4 & 5 & 5 & 0 & & 5 & 9 & & 7 & 7 & \\
\hline $\mathrm{NE} / \mathrm{AE}$ & 3 & 4 & 3 & & 5 & 5 & & 1 & 6 & 3 & & 3 & 4 & 3 & 0 & & 1 & 9 & & 3 & 7 & \\
\hline $\mathrm{AE} / \mathrm{NE}$ & 5 & 3 & 14 & 0.406 & 6 & 16 & 0.068 & 3 & 14 & 5 & 0.573 & 3 & 10 & 6 & 3 & 0.779 & 3 & 19 & 0.33 & 10 & 12 & 0.67 \\
\hline $\mathrm{AE} / \mathrm{AE}$ & 1 & 0 & 3 & & 3 & 1 & & 0 & 4 & 0 & & 1 & 2 & 1 & 0 & & 1 & 3 & & 1 & 3 & \\
\hline Total & 12 & 12 & 26 & & 16 & 34 & & 8 & 31 & 11 & & 11 & 21 & 15 & 3 & & 10 & 40 & & 21 & 29 & \\
\hline
\end{tabular}

Abbreviations: IHC, immunohistochemistry; NE, normal expression; AE, aberrant expression; ER/PR, estimation of estrogen and progesterone receptor expression, respectively; $\mathrm{P}$, positive (overexpression); N, negative (normal expression).

ladder of bands (Fig. 4B). These alterations were characterized as microsatellite instability (MI) as previously described $(50,53)$ MI was observed in all the microsatellite loci examined. In one of these cases, MI coexisted with LOH. Thus, in total, MAs (LOH and/or MI) at the 9p21-22 chromosomal region were detected in $20(36 \%)$ cases.

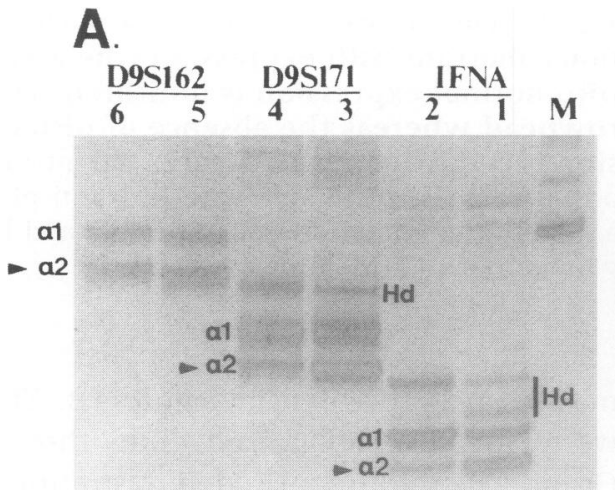

Fig. 4. Representative results of deletion mapping and microsatellite instability analysis with chromosome markers D9S162, D9S171, and IFNA and representative results of the PCRbased methylation assay. (A) $M$, marker (PUC19/ Sau3AI). Lanes 1-6, matched normal tumor samples (case 12) with polymorphism at the D9S162, D9S171, and IFNA loci and indication of loss of heterozygosity ( $\mathrm{LOH})$; (arrowhead). al and a2, alleles; Hd, heteroduplex lanes; LOH is shown with arrowhead). (B) Lanes 1 and 2, matched normal tumor samples (case 17) with no polymorphism at the D9S162 locus (Ho, homozygous), although the tumor sample showed MI, which is demonstrated as an aberrant band $\left(\alpha^{\prime}\right) ;($ arrow). Lanes 3 and 4 , matched normal
B.
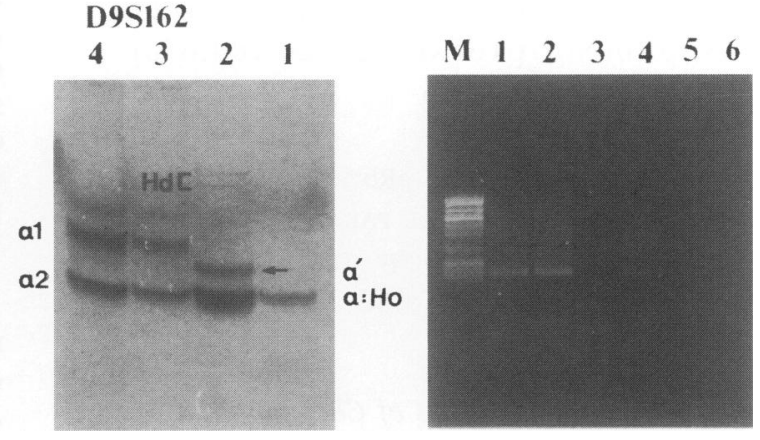

tumor samples with heterozygosity at $D 9 S 162$ locus (case 33). $\alpha 1$ and $\alpha 2$, alleles; $\mathrm{Hd}$, heteroduplex lanes. (C) De novo methylation of CDKN2/p16 ${ }^{I N K 4 a}$ exon la in a ductal breast carcinoma (case 8). $M$, marker (PUC19/Sau3AI). Lanes 1 and 2, undigested PCR products from matched normal tumor sample. Lanes 3 and 4, digestion with methylation-sensitive enzyme HpaII revealed that $C D K N 2 / p 16^{I N K 4 A}$ in nontumor tissue is unmethylated as no amplification by $\mathrm{PCR}$ is seen, whereas in the tumor, CDKN2/p16 ${ }^{I N K 4 A}$ is methylated as digestion does not affect amplification. Lanes 5 and 6, digestion with non-methylation-sensitive enzyme $M s p$ I affects amplification in normal and tumor tissue. 
In relation to clinicopathological parameters, we observed a highly significant association between MAs and tumor size $\left(p=9.2 \times 10^{-3}\right)$ and a probably significant correlation between MI and tumor size $(p=0.0526)$ (Table 3$)$.

\section{CDKN2/p16 $6^{I N K 4 A}$ Gene Methylation Analysis}

To address further the molecular basis of aberrant p16 expression, we examined the methylation status of $C D K N 2 / p 16^{I N K 4 A}$ exon la, which has been shown to correlate strongly with transcriptional silencing of the gene (54). We found that $11(20 \%)$ of the 55 carcinomas analyzed exhibited de novo methylation of exon la (Fig. 4C). Methylation patterns did not vary between HpaII and KspI. Furthermore, all normal tissues were unmethylated within the examined regions.

\section{SSCP Analysis of CDKN2/p1 $6^{I N K 4 A}$ Gene}

To assess point mutations and short nucleotide sequence insertions or deletions of the CDKN2/ $p 16^{I N K 4 A}$ gene, we used SSCP to analyze exons la and 2, obtained by PCR, from tumor and normal tissue-derived DNA. No tumor-specific migrational shifts were observed in any of the breast carcinomas studied.

\section{Relation between pl6 Immunohistochemical Findings, Microsatellite Alterations at 9p21-22 Locus, and Methylation Status of CDKN2/p16 $6^{\mathrm{INK} 4 \mathrm{~A}}$ Gene (Fig. 5)}

The cases with abnormal pl6 (AE) expression were placed in group $A$ and the cases with normal pl6 staining (NE) in group B. Group A was further divided into four subgroups according to the $\mathrm{LOH}(\mathrm{c})$ and methylation analysis results and group B into three subgroups according to $\mathrm{LOH}$ status. The carcinomas with inconclusive immunostaining were placed in group $\mathrm{C}$.

Statistical analysis revealed a correlation between aberrant expression of pl6 protein, MAs, and $\mathrm{LOH}$ at the 9p21-22 locus, respectively [MAs/pl6(AE) 14/26 (54\%) versus MAs/ pl6(NE) $4 / 25(16 \%), p=0.01$ and LOH/ pl6(AE) 9/26 (35\%) versus $\mathrm{LOH} / \mathrm{pl}$ (NE) $2 / 25$ $(8 \%), p=0.04]$. This association was even higher in the patients in group $\mathrm{LOH}(\mathrm{c})[\mathrm{LOH}(\mathrm{c}) /$ pl6(AE) $9 / 26(35 \%)$ versus $\mathrm{LOH}(\mathrm{c}) / \mathrm{pl}$ l6(NE) $1 / 25(4 \%), p=0.01]$. All the cases with de novo CDKN2/p16 ${ }^{I N K 4 A}$ methylation were accompanied with abnormal p16 staining (subgroups A2 and A3). Although the samples comprising subgroup
A4 did not show either $\mathrm{LOH}(\mathrm{c})$ or abnormal methylation status or SSCP tumor-specific shifts of CDKN2/p16 $6^{I N K 4 A}$, four of them demonstrated microsatellite instability.

\section{Discussion}

To the best of our knowledge, the results of our study, dealing mainly with the relation between abnormalities of the pl6-pRb pathway and alterations at the 9p21-22 region in sporadic invasive breast carcinomas, have not been reported so far.

The pl6-pRb pathway was investigated by immunohistochemistry, which allows evaluation of protein expression at the single-cell level $(16,17,30)$. In our approach, a mosaic pattern of staining was not interpreted as abnormal since, even in pl6- or pRb-positive cell lines, a subset of nuclei remained unstained because of cell-cycle fluctuations $(55,56)$. This can be explained by the findings that levels of pl6 may vary as much as 5 -fold during a cell cycle, the lowest occuring in G0 and early Gl phase (55). A similar situation has been described in pRb levels (56). In our study, sole cytoplasmic reactivity of p16 was disregarded. Its significance is unclear and has been observed by others (17). Interestingly, in a recent study, Marsh and Varley reported exclusive cytoplasmic pl6 expression in 21 out of $41(51 \%)$ breast lesions (24). Nevertheless, if cytoplasmic reactivity proves to be specific, one possible explanation for this could be that alteration in subcellular localization could represent an additional mechanism of pl6 inactivation. Wild-type p53 protein has an analogous mechanism of loss of function (57).

Aberrant pl6 was observed in $47 \%$ of the carcinomas. This is consistent with the findings of Gerardts and Wilson, who observed abnormal pl 6 protein staining in $49 \%$ of the breast carcinomas studied (16), while others have reported percentages ranging from $37 \%$ to $73 \%$ $(14,15,17,24)$. This discrepancy may be due to technical parameters of the assays and/or criteria of positivity. Furthermore, assessment of p16, as well as pRb, in breast tissue is challenging because the latter is hard to cut and process in pathology laboratories, thus leading frequently to prolonged fixation, which is responsible for "antigen loss." P16 protein appears to be particularly susceptible to fixation solutions and this may explain the inconclusive staining results observed by us and others (16).

To investigate the mechanisms that underlie $p 16^{I N K 4 A}$ inactivation, we examined the chromo- 


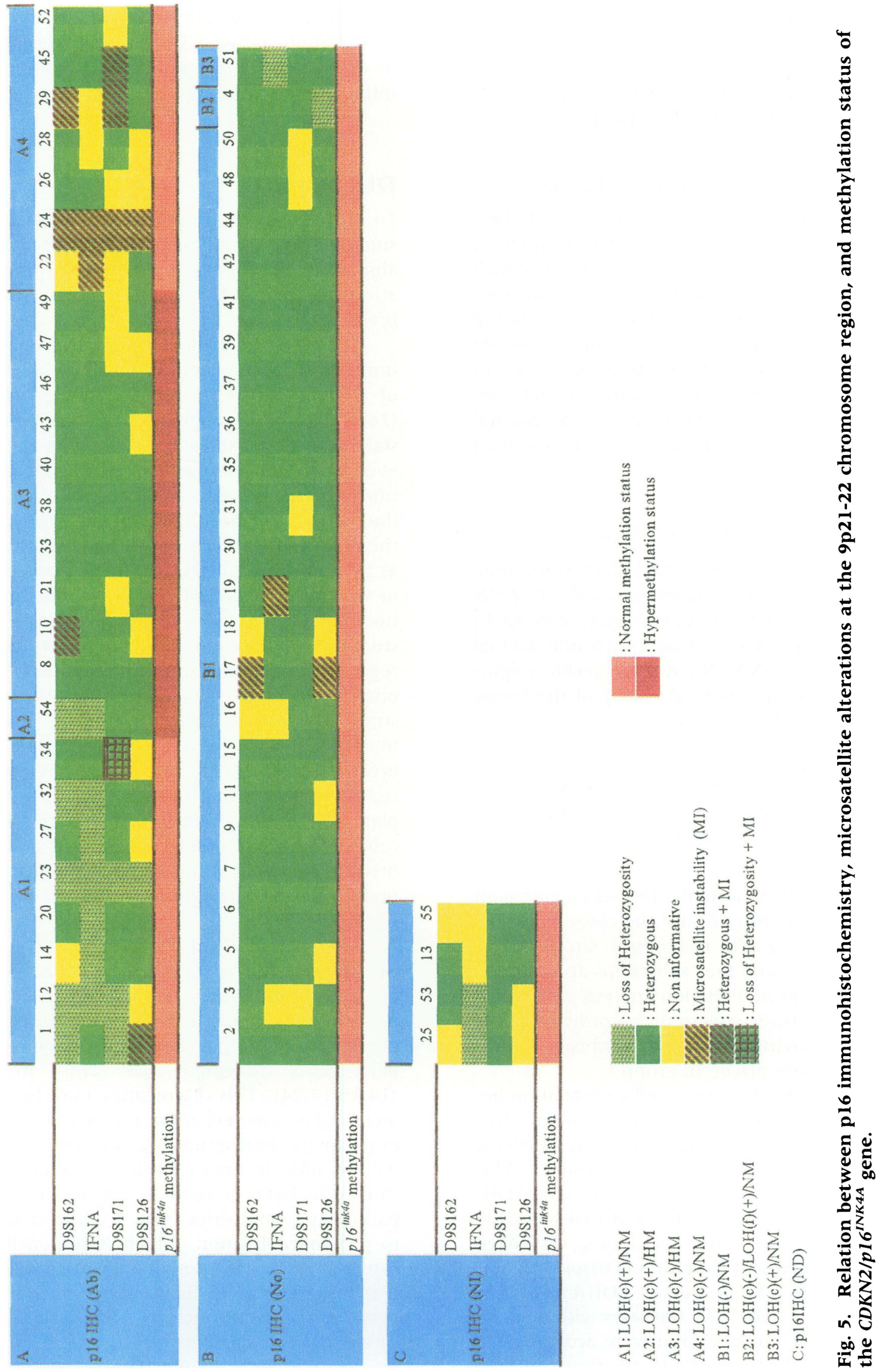


Table 3. Relationship of alterations at 9p21-22 chromosomal region with various clinicopathological parameters

\begin{tabular}{|c|c|c|c|c|c|c|c|c|c|c|c|c|c|c|c|c|c|c|c|c|c|c|}
\hline \multirow[b]{2}{*}{ IHC } & \multicolumn{4}{|c|}{ Tumor Size $(\mathbf{c m})$} & \multicolumn{3}{|c|}{$\begin{array}{l}\text { Lymph Node } \\
\text { Metastasis }\end{array}$} & \multicolumn{4}{|c|}{ Grade } & \multicolumn{5}{|c|}{ Stage } & \multicolumn{3}{|c|}{ ER } & \multicolumn{3}{|c|}{$\mathbf{P R}$} \\
\hline & $<2$ & 2 & $>2$ & $p$ & Yes & No & $p$ & $\mathbf{I}$ & II & III & $p$ & $\mathbf{I}$ & II & III & IV & $p$ & $\mathbf{P}$ & $\mathbf{N}$ & $p$ & $\mathbf{P}$ & $\mathbf{N}$ & $p$ \\
\hline \multicolumn{23}{|l|}{ MA } \\
\hline+ & 2 & 2 & 16 & \multirow{3}{*}{0.0091} & 13 & 7 & \multirow{3}{*}{0.7860} & 2 & 10 & 5 & \multirow{3}{*}{0.7149} & 3 & 7 & 7 & 2 & \multirow{3}{*}{0.3971} & 2 & 14 & \multirow{3}{*}{0.8203} & 7 & 9 & \multirow{3}{*}{0.6402} \\
\hline- & 12 & 10 & 13 & & 24 & 11 & & 7 & 19 & 8 & & 10 & 17 & 7 & 2 & & 5 & 29 & & 11 & 23 & \\
\hline Total & 14 & 12 & 29 & & 37 & 18 & & 9 & 29 & 13 & & 13 & 24 & 14 & 4 & & 7 & 43 & & 18 & 32 & \\
\hline \multicolumn{23}{|l|}{$\mathrm{LOH}$} \\
\hline+ & 1 & 2 & 10 & \multirow{3}{*}{0.1151} & 9 & 4 & \multirow{3}{*}{0.8633} & 1 & 8 & 3 & \multirow{3}{*}{0.9202} & 3 & 3 & 5 & 2 & \multirow{3}{*}{0.2286} & 2 & 8 & \multirow{3}{*}{0.9188} & 3 & 7 & \\
\hline- & 13 & 10 & 19 & & 28 & 14 & & 8 & 21 & 10 & & 10 & 21 & 9 & 2 & & 5 & 35 & & 15 & 25 & \multirow[t]{2}{*}{0.9413} \\
\hline Total & 14 & 12 & 29 & & 37 & 28 & & 9 & 29 & 13 & & 13 & 24 & 14 & 4 & & 7 & 43 & & 18 & 32 & \\
\hline \multicolumn{23}{|l|}{ MI } \\
\hline+ & l & 0 & 8 & \multirow{3}{*}{0.0527} & 6 & 3 & \multirow{3}{*}{0.9662} & 1 & 3 & 3 & \multirow{3}{*}{0.5242} & 0 & 4 & 4 & 1 & \multirow{3}{*}{0.2320} & 0 & 8 & \multirow{3}{*}{0.4906} & 4 & 4 & \multirow{3}{*}{0.6183} \\
\hline- & 13 & 12 & 21 & & 31 & 15 & & 8 & 26 & 10 & & 13 & 20 & 10 & 3 & & 7 & 35 & & 14 & 28 & \\
\hline Total & 14 & 12 & 29 & & 37 & 18 & & 9 & 29 & 13 & & 13 & 24 & 14 & 4 & & 7 & 43 & & 18 & 32 & \\
\hline
\end{tabular}

Abbreviations: MA, microsatellite alteration; LOH, loss of heterozygosity; MI, microsatellite instability; $+/-$, presence or absence of specified genetic alteration; ER/PR, estimation of estrogen and progesterone receptor expression, respectively; $\mathrm{P}$, positive (overexpression); $\mathrm{N}$, negative (normal expression).

somal region 9p2l-22 by $\mathrm{LOH}$ analysis using closely spaced microsatellite markers (Fig. 1A) and the methylation and structural status of the pl $6^{I N K 4 A}$ gene by a PCR-based methylation assay and PCR-SSCP analysis, respectively. The findings were then correlated with the results of immunohistochemistry. A statistically significant association was observed between $\mathrm{LOH}(c)$ and abnormal pl6 protein staining $(p=0.01)$ (Fig. 5), suggesting that deletions may represent an important mode of $p 16^{I N K 4 A}$ gene inactivation. Several groups have investigated $p 16^{I N K 4 A}$ gene deletions in breast tumors, using Southern blotting and dublex-PCR assays, producing controversial results $(20-23,25)$. These differences may be due to contamination of the homogenates by non-neoplastic cells and aneuploidy of tumor cells. The current microdissection techniques have ameliorated but not completely solved this problem. Furthermore, we observed that $42 \%$ of the breast carcinomas with aberrant pl 6 expression were hypermethylated, supporting the hypothesis that methylation of the $5^{\prime} \mathrm{CpG}$ island within the first exon of the $p 16^{I N K 4 A}$ gene correlates with transcriptional silencing (subgroups A2 and A3, Fig. 5) (54). In addition, no methylation of $p 16^{I N K 4 A}$ in adjacent normal breast tissue was observed. Our findings are in accordance with the results of Herman et al., although, they did not mention evaluation of $p 16^{I N K 4 A}$ methylation in normal breast tissue (19). In contrast,
Van Zee and co-workers demonstrated that normal breast tissue exhibits $p 16^{I N K 4 A}$ methylation more frequently than breast carcinoma, suggesting that its expression in carcinoma cells may represent an unsuccessful attempt to limit growth in cells lacking some other normal mechanisms of control (27). Similar discordances are reported in studies concerning the methylation status of $p 16^{I N K 4 A}$ in colon cancer tissue and normal colonic mucosa $(27,58,59)$. Contamination of the normal epithelial cells with cells of different origin or partial digestion with the methylsensitive enzymes used could account for the aforementioned differences. PCR-SSCP analysis of exons la and 2 in our study did not reveal any minor structural alterations, which supports previous evidence suggesting that intragenic p16 ${ }^{I N K 4 A}$ alterations are infrequent events in breast carcinomas $(20-23,25)$. Thus, overall, 19 of the 26 cases $(73 \%)$ with abnormal pl 6 protein staining had $\mathrm{LOH}(\mathrm{c})$ and/or abnormal methylation status of the CDKN2/p16 $6^{I N K 4 A}$ gene (Fig. 5). Therefore, taking together our data and those reported thus far, it appears that deletions and transcriptional silencing by methylation might be the predominant mechanisms that inactivate $p 16^{I N K 4 A}$ gene in breast carcinomas. The seven cases $(27 \%)$ of subgroup A4 with loss of pl 6 did not show obvious genetic and epigenetic alterations (Fig. 5). One possible explanation for aberrant pl6 expression in these cases is that the 
microsattelite markers used were not sufficient to detect small deletions in the CDKN2/p16 $6^{I N K 4 A}$ region. Alternatively, the presence of normal contaminating DNA may contribute to a retention pattern in cases with homozygous deletion. A third possibility that could account for loss of protein expression is mutations outside the examined region; such is the case of the mutation being in the second intron splice donor site, which results in a smaller pl6 protein with a reduced half-life, possibly undetectable by immunohistochemistry (60). The retention of pl6 protein expression in case 51 (subgroup B3) suggests either alterations of another TSG(s) located in the 9p21-22 region and/or a compensatory mechanism by the remaining CDKN2/p16 $6^{I N K 4 A}$ allele.

Deletion mapping studies have shown that the frequency of alterations of the 9p21-22 region in primary breast tumors are higher than those reported for $C D K N 2 / p_{16} 6^{I N K 4 A}(20-23$, 25,26 ). In the present study LOH was observed in $24 \%$ of the samples, which is lower with the findings presented by the other groups $(22,26)$ and comparable to the percentage of $\mathrm{LOH}(\mathrm{c})$ $(22 \%)$. Despite the low frequency of losses flanking the $C D K N 2 / p 16^{I N K 4 A}$ area $(11 \%$ at $D 9 S 162$ and $5 \%$ at $D 9 S 126), 83 \%$ of them were accompanied by $\mathrm{LOH}(\mathrm{c})$. The D9S162 and D9S126 loci are placed $6 \mathrm{cM}$ and $1 \mathrm{cM}$ away from IFNA and D9S171, respectively, and have been proposed to lie near the location of putative TSG(s) $(41,60,61)$. The talin gene has recently been mapped in this region (62) and its product is a critical molecule for the formation of focal adhesions. Inactivation of talin disassembles many of these structures (63). Talin, therefore, is a gene candidate for a role in breast carcinogenesis. It is possible that co-deletion of this candidate TSG(s) with $C D K N 2 / p 16^{I N K 4 A}$ is important in the development of a subset of invasive breast carcinomas. Marsh and Varley noticed that LOH at D9S162 was more commonly observed in ductal in situ carcinomas (DCIS) and invasive carcinomas with a DCIS component $(41 \%)$ than solely invasive carcinomas $(10 \%)(26)$. Moreover, in a recent study we found a high deletion frequency at loci D9S162 and D9S126 in non-small-cell lung carcinomas (64). Taking together our data and those reported thus far, we can speculate that if an additional TSG(s) exists in the 9p21-22 region, its involvement in carcinogenesis is probably tissueand histology-dependent. In addition to $\mathrm{LOH}$, microsatellite analysis revealed microsatellite instability (MI) in $16 \%$ of carcinomas. Only one tumor exhibiting MI showed evidence of $\mathrm{LOH}$, a finding in accordance with the inverse correlation found between MI and LOH in colorectal cancer (65). MI provides a marker for mutator or replication error phenotype $(\mathrm{RER}+)$, a recently defined manifestation of genetic instability. It has been observed in both hereditary and sporadic cancers, and it is caused by a deficiency of DNA mismatch repair genes (MMR) (66). The inability to detect DNA mismatches during replication can result in structural gene alterations that can lead to deregulated function of the cell-cycle control machinery. For example, mutations in the transforming growth factor $\beta$ (TGF- $\beta$ ) type II receptor have been found in colon cancer cell lines with MI, resulting in enhanced tumorigenicity (67). In a similar manner, the high frequency of $\mathrm{MI}$ observed in subgroup A4 may represent an additional mechanism of $C D K N 2 / p 16^{I N K 4 A}$ gene deregulation. The data concerning $\mathrm{MI}$ in breast cancer are conflicting with respect to the frequency and affected repeat sequences (68-73). Considering the frequency, our percentage is closer to that of Wooster et al. (69) and Yee et al. (70), who found MI in $10 \%$ and $20 \%$ of the cases examined, respectively. In two other reports, MI occured in $5 \%(68)$ and $30 \%(71)$ of breast carcinomas. High levels of MI were also noted by Patel et al. for specific loci on chromosomes $2 p$, $8 p$ and $10 p(72)$, while Glebov et al. noticed differences in MI between tumors with a family history and sporadic breast cancers (73). As far as the repeat sequence pattern is concerned, we observed that dinucleotide repeats are frequently affected, although we did not include tri- and tetranucleotide motifs in our study. This finding is in agreement with the results of Yee et al. (70) but differs from those of others where MI was noted mainly in trinucleotide $(68,69)$ and tetranucleotide repeats (71). More studies are needed to clarify whether these variations in susceptibility of microsatellite sequences reflect the involvement of different mutated MMR genes, different mechanisms for generating MI, or simply differences in experimental design.

Abnormal loss of $\mathrm{pRb}$ expression was found in $29 \%$ of our cases, which is in accordance with the reported incidence of other series $(14,32-$ 35,37 ). Serrano et al. have proposed a negative feedback model, showing that inactivation of $\mathrm{pRb}$ during $\mathrm{Gl}$ leads to increased pl6 expression to limit CDK4 activity (5). Several studies in various tumors, including breast, have demonstrated a reciprocal relation between $\mathrm{pRb}$ and pl 6 (74-77). In this cohort we noticed a statistical trend pointing out the inverse correlation between pl6 and pRb expression $(p=0.079)$ 
which would agree with the proposed model. However, $29 \%$ of the cases with reduced expression of $\mathrm{pRb}$ showed corresponding aberrant pl6 staining. Recently, Marsh and Varley (24) also reported simultaneous abnormal pl6 and pRb expression in a significant proportion $(41 \%)$ of breast lesions. A similar phenomenon has been noted by Wang and Becker in the melanocytic system (78), by Hangaishi et al. in primary lymphoid malignancies (79), and by our group in non-small-cell lung carcinomas (64). Since several lines of evidence suggest that functional $\mathrm{pRb}$ is essential for cell-cycle inhibition by pl6 (80), inactivation of pl6 in a cell without functional $\mathrm{pRb}$ is not likely to confer additional growth advantage to the cancerous cell. In carcinomas with double hits, one possible explanation is that pl6 inactivation is an early event followed by subsequent loss of $\mathrm{pRb}$. This mechanism could contribute to advantageous tumor growth by cancelling all the incoming inhibitory signals to $\mathrm{pRb}$ from the other cyclin-dependent kinase inhibitors (CDKIs) (81). In this respect, our findings that p16 inactivation was noticed in almost half of the carcinomas and its frequency was higher than loss of $\mathrm{pRb}$, in addition to the lack of association with tumor stage, suggest an early involvement of $C D K N 2$ alterations in breast cancer development. This can be further supported by the study of Dublin et al., who also did not notice an association between loss of pl6 and clinical stage in breast carcinomas (14). Alternatively, pl6 may participate in other unknown pRb-independent pathways. This assumption can be sustained by the finding that pl 6 inactivation causes stimulation of cyclin D2 and D3, which may act on other substrates besides $\mathrm{pRb}$ (81).

The relation between $\mathrm{pl} 6$ status, $\mathrm{pRb}$ protein level, the pl6-pRb immunophenotypes, and the alterations detected at the 9p21-22 locus with the patients' clinicopathological parameters revealed only two significant correlations: one between positive $\mathrm{pRb}$ reaction and lymph node involvement $(p=0.026)$, and the other between microsatellite alterations and tumor size $(p=$ $\left.9.2 \times 10^{-3}\right)$. Our observation regarding strong $\mathrm{pRb}$ expression and lymph node metastases is surprisingly unusual. One would expect loss (rather than increased expression) of an oncosuppressor to be associated with an adverse prognostic parameter. A number of studies in breast cancer have examined the association of $\mathrm{pRb}$ with various prognostic parameters and have reported controversial findings. In a large series of breast carcinomas, Trudel et al. found an associ- ation between strong $\mathrm{pRb}$ reaction and high nuclear grade tumors (38), while Berns et al. observed that $R B 1$ gene alterations were significantly more frequent in node-negative patients and Tl tumors (34). No relation among various clinical parameters, including grade, nodal status, stage or receptor status, was found by Thorlacius et al. (82). In contrast, the results of other works have shown a correlation between $R B 1$ alterations and/or protein loss and poor prognostic indicators, such as poorly differentiated tumors $(14,37)$, positive lymph node status (36), and increased proliferative activity (35). With respect to the relation between $R B I$ alterations and survival in breast cancer, the few published studies have shown no association. From these contrasting data, it is difficult to draw a specific picture of the role of the $R B 1$ gene in sporadic breast cancer. The conflicting results could be due to the variety of techniques used to estimate $R B I$ status and expression. The accuracy of molecular studies may be affected by normal tissue "contamination", while immunohistochemistry has the advantage of evaluating protein expression at the single-cell level. However, in the case of $\mathrm{pRb}$, immunohistochemistry gives no indication of the protein's phosphorylation status and therefore, of its activity state, nor does it distinguish mutant from wild-type $\mathrm{pRb}$ proteins. Hence, it is possible that this could be the case in certain samples of our study. With regard to our second significant finding, there has been no previous report of a correlation between microsatellite alterations at the 9p21-22 chromosomal region and a poor prognostic indicator, such as tumor size. Interestingly, we also observed a probably significant association between MI and tumor size $(p=0.05)$, which is in keeping with the work of Paulson et al., who demonstrated a correlation with factors commonly related to poor prognosis (71). But this finding contrasts with other studies suggesting that $\mathrm{MI}$ is an early event in mammary tumorigenesis $(68,70)$. Finally, the data concerning the relation between p16 and prognostic features are few $(14,15)$. Dublin et al. unexpectedly found a strong association between pl6-positive staining and poor prognosis (14), while Ito et al. reported that abnormal pl 6 immunoreactivity was more frequent in tumors of larger size and/or higher stage (15).

In view of the heterogenous nature of breast cancer, the large number of genetic targets recognized, and the overlapping and compensatory pathways linking most of them, we suggest that in a significant proportion of breast carcinomas, 
deregulation of the pl6-pRb pathway in association with other unidentified TSG(s) of the 9p21-22 region may play a role in initiating or advancing the oncogenic procedure, whereas in other subgroups, alternative molecules may play this role.

\section{Acknowledgments}

This work was funded by National Greek Health Committee (KESY) grant Y3 $\alpha / 2442 / 12-11-97$ for research protocols and "Lilly" pharmaceutical company.

\section{References}

1. Boring CC, Squires TS, Tong T, Montgomery S. (1994) Cancer Stat. CA 44: 7.

2. Deville P, Cornelisse CJ. (1994) Somatic genetic changes in human breast cancer. Biochim. Biophys. Acta 1198: 113-130.

3. Cordon-Cardo C. (1995) Mutations of cell cycle regulators. Am. J. Pathol. 147: 545-560.

4. Haber DA. (1997) Splicing into senescence: The curious case of pl6 and p19ARF. Cell 91: 551-558.

5. Serrano M, Hannon G, Beach D. (1993) A new regulatory motif in cell-cycle control causing specific inhibition of cyclin D/CDK4. Nature 366: 704-707.

6. Kamb A, Gruis NA, Weaver-Feldhaus J, Liu Q, Harshman K, Tavtigian SV. (1994) A cell cycle regulator potentially involved in genesis of many tumor types. Science 264: 436-440.

7. Knudson AG. (1993) Antioncogenes and human cancer. Proc. Natl. Acad. Sci. U.S.A. 90: 10914-10921.

8. Nobori T, Miura K, Wu DJ, Lois A, Takabayashi K, Carson DA. (1994) Deletions of the cyclin-dependent kinase-4 inhibitor gene in multiple human cancers. Nature 368: 753-756.

9. Cairns P, Mao L, Merlo A. (1994) Rates of the pl6 (MTS1) mutations in primary tumours with $9 p$ loss. Science 265: 415-416.

10. Okamoto A, Demetrick DJ, Spillare EA, et al. (1994) Mutations and altered expression of pl6INK4 in human cancer. Proc. Natl. Acad. Sci. U.S.A. 91: 11045-1 1049.

11. Spruck CH III, Gonzalez-Zulueta M, Shibata A, et al. (1994) pl6 gene in uncultured tumours. Nature 370: $183-184$.

12. Zhang S-Y, Klien-Szanto AJP, Sauter ER, et al. (1994) Higher frequency of the alterations in the p16/CDKN2 gene in squamous cell carcinoma cell lines than in primary tumours of the head and neck. Cancer Res. 54: 5050-5053.

13. Reissmann PT, Koga H, Takahashi R, et al. (1993) The Lung Cancer Study Group. Inactivation of the retinoblastoma susceptibity gene in non-small-cell lung cancer. Oncogene 8: 1913-1919.
14. Dublin EA, Patel NK, Gillett CE, Smith P, Peters G, Barnes DM. (1998) Retinoblastoma and pl6 proteins in mammary carcinoma: their relationship to cyclin D1 and histopathological parameters. Int. J. Cancer 79: 71-75.

15. Ito $Y$, Kobayashi T, Takeda T, et al. (1997) Expression of pl 6 and cyclin-dependent kinase 4 proteins in primary breast carcinomas. Oncology 54: 508-515.

16. Geradts J, Wilson PA. (1996) High frequency of aberrant pl6ink4A expression in human breast cancer. Am. J. Pathol. 149: 15-20.

17. Merlo A, Mabry M, Gabrielson E, Vollmer R, Baylin SB, Sidransky D. (1993) Frequent microsatellite instability in primary small cell lung cancer. Cancer Res. 54: 2098-2101.

18. Rush EB, Abouezzi Z, Borgen PI, Anelli A. (1995) Analysis of MTS1/CDK4 in female breast carcinomas. Cancer Lett. 89: 223-226.

19. Herman JG, Merlo A, Mao L, et al. (1995) Inactivation of the CDKN2/p16/MTS1 gene is frequently associated with aberrant DNA methylation in all common human cancers. Cancer Res. 55: 45254530.

20. Quesnel B, Fenaux P, Philippe N, et al. (1995) Analysis of pl 6 gene deletion and point mutation in breast carcinoma. Br. J. Cancer 72: 351-353.

21. Berns EMJJ, Klijn JGM, Smid M, van Staveren IL, Gruis NA, Foekens JA. (1995) Infrequent CDKN2 (MTS1/p16) gene alterations in human primary breast cancer. Br. J. Cancer 72: 964-967.

22. Brenner AJ, Aldaz CM. (1995) Chromosome 9p allelic loss and $p 16 / C D K N 2$ in breast cancer and evidence of $p 16$ inactivation in immortal breast epithelial cells. Cancer Res. 55: 2892-2895.

23. Xu L, Sgroi D, Sterner CJ, et al. (1994) Mutational analysis of $C D K N 2\left(M T S 1 / p 16^{\text {ink4 }}\right)$ in human breast carcinomas. Cancer Res. 54: 5262-5264.

24. Marsh KL, Varley JM. (1998) Frequent alterations of cell cycle regulators in early-stage breast lesions as detected by immunohistochemistry. Br. J. Cancer 77: 1460-1467.

25. Musgrove EA, Lilischkis $\mathrm{R}$, Cornish $\mathrm{AL}$, et al. (1995) Expression of the cyclin-dependent kinase inhibitors $\mathrm{pl} 6^{\mathrm{INK} 4}, \mathrm{p} 15^{\mathrm{INK} 4 \mathrm{~B}}$ and $\mathrm{p} 21^{\text {WAF1/Cipl }}$ in human breast cancer. Int. J. Cancer 63: 584-591.

26. Marsh KL, Varley JM. (1998) Loss of heterozygosity at chromosome $9 p$ in ductal carcinoma in situ and invasive carcinoma of the breast. Br. J. Cancer 77: 1439-1447.

27. Van Zee KJ, Calvano JE, Bisogna M. (1998) Hypomethylation and increased gene expression of p16 ${ }^{I N K 4 a}$ in primary and metastatic breast carcinoma as compared to normal breast tissue. Oncogene 16: 2723-2727.

28. T'Ang A, Varley JM, Chakraborty S, Murphree AL, Fung Y-KT. (1989) Structural rearrangement of the retinoblastoma gene in human breast carcinoma. Science 242: 263-266.

29. Barbareschi M, Pelosio P, Caffo O, et al. (1997) $C y c l i n-D 1$-gene amplification and expression in 
breast carcinoma: relation with clinicopathologic characteristics and with retinoblastoma gene product, $\mathrm{p} 53$ and $\mathrm{p} 21^{\mathrm{WAF} 1}$ immunohistochemical expression. Int. J. Cancer 74: 171-174.

30. Geradts J, Hu S-X, Lincoln CE, Benedict WF, Xu H-J. (1994) Aberrant $R b$ gene expression in routinely processed, archival tumor tissues determined by three different anti-Rb antibodies. Int. $J$. Cancer 58: 161-167.

31. Nielsen NH, Emdin SO, Cajander J, Landberg G. (1997) Deregulation of cyclin E and Dl in breast cancer is associated with inactivation of the retinoblastoma protein. Oncogene 14: 295-304.

32. Borg A, Zhang Q-X, Alm P, Olsson H, Sellberg G. (1992) The retinoblastoma gene in breast cancer: allele loss is not correlated with loss of gene protein expression. Cancer Res. 52: 2991-2994.

33. Anderson JJ, Tiniakos DG, Mcintosh GG, et al. (1996) Retinoblastoma protein in human breast carcinoma: immunohistochemical study using a new monoclonal antibody effective on routinely processed tissues. J. Pathol. 180: 65-70.

34. Berns EMJJ, Klein A, van Putten WLJ, et al. (1995) Association between $R B-1$ gene alterations and factors of favourable prognosis in human breast cancer, without effect on survival. Int. J. Cancer 64: 140-145.

35. Jares P, Rey MJ, Fernandez PL, et al. (1997) Cyclin $\mathrm{Dl}$ and retinoblastoma gene expression in human breast carcinoma: correlation with tumour proliferation and oestrogen receptor status. J. Pathol. 182: 160-166.

36. Sawan A, Randall B, Angus B, et al. (1992) Retinoblastoma and p53 gene expression related to relapse and survival in human breast cancer: an immunohistochemical study. J. Pathol. 168: 2328.

37. Varley JM, Armour J, Swallow JE, et al. (1989) The retinoblastoma gene is frequently altered leading to loss of expression in primary breast tumours. Oncogene 4: 725-729.

38. Trudel M, Mulligan L, Cavenee W, Margolese R, Cote J, Cariepy G. (1992) Retinoblastoma and p53 product expression in breast carcinoma: immunohistochemical analysis and clinicopathologic correlation. Hum. Pathol. 23: 1388-1394.

39. Koh J, Enders GH, Dynlacht BD, Harlow E. (1995) Tumour-derived pl6 alleles encoding proteins defective in cell-cycle inhibition. Nature 375: 506-510.

40. Li Y, Nichols MA, Shay JW, Xiong Y. (1994) Transcriptional repression of the D-type cyclin-dependent kinase inhibitor pl 6 by the retinoblastoma susceptibility gene product pRb. Cancer Res. 54: 6078-6082.

41. Wiest JS, Franklin WA, Otstot JT, et al. (1997) Identification of a novel region of homozygous deletion on chromosome $9 p$ in squamous cell carcinoma of the lung: the location of a putative tumor suppressor gene. Cancer Res. 57: 1-7.

42. Olopade OI, Pomykala HM, Hagos F, et al. (1995) Construction of a 2.8-megabase yeast artificial chromosome contig and cloning of the human methylthioadenosine phosphorylase gene from the tumor suppressor region on $9 \mathrm{p} 21$. Proc. Natl. Acad. Sci. U.S.A. 92: 6489-6493.

43. Bloom HJG, Richardson WW. (1957) Histologic grading and prognosis in breast cancer. A study of 1509 cases of which 359 have been followed for 15 years. Br. J. Cancer 11: 359-377.

44. Kinne DW. (1991) Staging and follow-up of breast cancer patients. Cancer 67: 1188-1198.

45. Mouridsen HT, Palshof T, Mattheiem W, Sylvester RJ, Rotmensz N, Paridaeus RJ. (1984) Currently active protocols in the EORTC Breast Cancer Cooperative Group. Recent Results Cancer Res. 91: 263267.

46. Gorgoulis V, Rassidakis G, Karameris A, et al. (1996) Immunohistochemical and molecular evaluation of the MDM2 gene product in bronchogenic carcinoma. Mod. Pathol. 9: 544-554.

47. Gorgoulis V, Zoumpourlis V, Rassidakis G, et al. (1996) A molecular and immunohistochemical study of the MDM2 protein isoforms and $p 53$ gene product in bronchogenic carcinoma. J. Pathol. 180: 129-137.

48. Whetsell L, Maw G, Nadon N, Ringer D, Schaefer F. (1995) Polymerase chain reaction microanalysis of tumors from stained histological slides. Oncogene 7: 581-585.

49. Davis LG, Dibner MD, Battey JF. (1986) Basic Methods in Molecular Biology. Elsevier Science Publishing, New York.

50. Fong KM, Zimmermann PV, Smith PJ. (1995) Microsatellite instability and other molecular abnormalities in non-small cell lung cancer. Cancer Res. 55: 28-30.

51. Chaubert P, Guillou L, Kurt A-M, et al. (1997) Frequent pl $^{I N K 4}$ (MTS1) gene inactivation in testicular germ cell tumors. Am. J. Pathol. 151: 859-865.

52. Gorgoulis V, Zoumpourlis V, Rassidakis G, et al. (1995) Molecular analysis of p53 gene in laryngeal premalignant and malignant lesions: $\mathrm{p} 53$ protein immunohistochemical expression is positively related to proliferating cell nuclear antigen labelling index. Virchows Arch. 426: 339-344.

53. Merlo A, Mabry M, Gabrielson E, Vollmer R, Baylin SB, Sidransky D. (1993) Frequent microsatellite instability in primary small cell lung cancer. Cancer 54: 2098-2101.

54. Otterson GA, Kleif SN, Chen W, Coxon AB, Kaye FJ. (1995) CDKN2 gene silencing in lung cancer by DNA hypermethylation and kinetics of $\mathrm{pl}^{\mathrm{INK} 4}$ protein induction by 5-aza $2^{\prime}$ deoxycytidine. Oncogene 11: 1211-1216.

55. Tam SW, Stay JW, Pagano M. (1994) Differential expression and cell cycle regulation of the cyclindependent kinase 4 inhibitor p16 $6^{\mathrm{INK} 4}$. Cancer Res. 54: 5816-5820.

56. Xu H-J, Hu S-X, Benedict WF. (1991) Lack of nuclear RB protein staining in $\mathrm{G} 0 /$ middle $\mathrm{Gl}$ cells: correlation to changes in total RB protein level. Oncogene 6: 1139-1146.

57. Zambetti GP, Levine AJ. (1993) A comparison of 
the biological activities of wild type and mutant p53. FASEB J. 7: 855-865.

58. Merlo A, Herman JG, Mao L, et al. (1995) 5' CpG island methylation is associated with traditional silencing of the tumor suppressor p16/CDKN2/ MTS1 in human cancers. Nat. Med. 1: 686-692.

59. Gonzalez-Zulueta $M$, Bender CM, Yang AS, et al. (1995) Methylation of the 5' CpG island of the p16/CDKN2 tumor suppressor gene in normal and transformed human tissues correlates with gene silencing. Cancer Res. 55: 4531-4535.

60. Vos S, Miller C, Takeuchi S, Combart A, Cho S, Koeffler H. (1995) Alteration of CDKN2 (pl6) in non-small cell lung cancer. Genes Chromosom Cancer 14: 164-170.

61. Neville EM, Stewart M, Myskow M, Donnelly RJ, Field JK. (1995) Loss of heterozygosity at 9p23 defines a novel locus in non-small cell cancer. Oncogene 11: 581-585.

62. Gilmore AP, Ohanian V, Spurr NK, Critchley DR. (1995) Localisation of the human gene encoding the cytoskeletal protein talin to chromosome $9 \mathrm{p}$. Hum. Genet. 96: 221-224.

63. Albiges-Rizo C, Frachet P, Block MR. (1995) Down regulation of talin alters cell adhesion and the processing of the $\alpha 5 \beta 1$ integrin. J. Cell Sci. 108: 3317-3329.

64. Gorgoulis VG, Zacharatos P, Kotsinas A, et al. (1998) Alterations of the p16-pRb pathway and the chromosome locus 9p21-22 in non-small cell lung carcinomas (NSCLCs). Relationship with p53 and MDM2 protein expression. Am. J. Pathol. 153: 1749-1765.

65. Thibodeau SN, Bren G, Schaid D. (1993) Microsatellite instability in cancer of the proximal colon. Science 260: 816-819.

66. Jiricny JT. (1994) Colon cancer and DNA repair: have mismatches met their match? Trends Genet. 4: 164-168.

67. Markowitz S, Wang J, Myeroff L, et al. (1995) Inactivation of the type II TGF-beta receptor in colon cancer cells with microsatellite instability. Science 268: 1336-1338.

68. Shaw JA, Chappell SA, Carey N, Johnson K, Walker RA. (1996) Microsatellite instability in early sporadic breast cancer. Br. J. Cancer 73: 1393-1397.

69. Wooster R, Clenton-Jansen AM, Collins N, et al. (1994) Instability of short tandem repeats (microsatellites) in human cancers. Nat. Genet. 6: 152-156.

70. Yee CJ, Roodi N, Verrier CS, Parl FF. (1994) Mi- crosatellite instability and loss of heterozygosity in breast cancer. Cancer Res. 54: 1641-1644.

71. Paulson TG, Wright FA, Parker BA, Russack V, Wahl GM. (1996) Microsatellite instability correlates with reduced survival and poor disease prognosis in breast cancer. Cancer Res. 56: 4021-4026.

72. Patel U, Grundfest-Broniatowski S, Gupta M, Banerjee S. (1994) Microsatellites instabilities at five chromosomes in primary breast tumours. Oncogenes 9: 3695-700.

73. Glebov OK, McKenzie KE, White CA, Sucumar S. (1994) Frequent $p 53$ gene mutations and novel alleles in familial breast cancer. Cancer Res. 54: 3703-3709.

74. Sakaguchi M, Fujii Y, Hirabayashi H, et al. (1996) Inversely correlated expression of pl 6 and $\mathrm{Rb}$ protein in non-small cell lung cancers: an immunohistochemical study. Int. J. Cancer 65: 442-445.

75. Kinoshita I, Dosaka-Akita H, Mishina T, et al. (1996) Altered p16 $6^{\mathrm{INK} 4}$ and retinoblastoma protein status in non-small cell lung cancer: potencial synergistic effect with altered p 53 protein on proliferative activity. Cancer Res. 56: 5557-5562.

76. Yeager T, Stadler W, Belair C, Puthenveettil J, Olopade O, Reznikoff C. (1995) Increased pl6 levels correlate with $\mathrm{pRb}$ alterations in human urothelial cells. Cancer Res. 55: 493-497.

77. Ueki K, Ono Y, Henson JW, Efird JT, von Diemling A, Louis DN. (1996) CDKN2/pl 6 or RB alterations occur in the majority of glioblastomas and are inversely correlated. Cancer Res. 56: 150-153.

78. Wang Y, Becker D. (1996) Differential expression of the cyclin-dependent kinase inhibitors pl 6 and p21 in the human melanocytic system. Oncogene 12: 1069-1075.

79. Hangaishi A, Ogawa S, Imamura N, et al. (1996) Inactivation of multiple tumor-suppressor genes involved in negative regulation of the cell cycle, MTS1/ $p 16^{I N K 4 A}, M T S 2 / p 15^{I N K 4 B}, p 53$, and $R b$ genes in primary lymphoid malignancies. Blood 87: 4949-4958.

80. Medema RH, Herrera RE, Lam F, Weinberg RA. (1995) Growth suppression by pl6 ${ }^{\text {ink4 }}$ requires functional retinoblastoma protein. Proc. Natl. Acad. Sci. U.S.A. 92: 6289-6293.

81. Bernards R. (1997) E2F: a nodal point in cell cycle regulation. Biochem. Biophys. Acta 1333: M33-40.

82. Thorlacius S, Jonasdottir O, Eyfjord JE. (1991) Loss of heterozygosity at selective sites on chromosomes 13 and 17 in human breast carcinoma. Anticancer Res. 11: 1501-1508. 